\title{
Law Principles of Contract Interpretation Based on Indonesian Civil Code
}

\author{
Hervian Yulia Rumengan \\ Faculty of Law \\ University of Brawijaya \\ Malang, Indonesia \\ hervian_rumengan@yahoo.com
}

\begin{abstract}
Occasionally, in an agreement which is a basic form of contract originated from any deal or approval between two parties that bind themselves against others, there is different interpretation from each party that designs the contract. This research is aimed at reviewing the law principles of contract interpretation based on Indonesian Civil Code. It was conducted by using scientific methods, either in data collection or in data analysis. The results show that the law principles of contract interpretation based on Indonesian Civil Code takes possession of three methods, namely: (1) a subjective interpretation method is where the contract interpretation is designed by following an optimally possibility from what is meant truly from the side; (2) the objective interpretation method stresses on what is written in any contract; (3) the interpretation method between the objective and subjective one is that an interpretation that deals with between the objective interpretation method and the subjective one. The contract interpretation for the lost party which provides the draft contract or clause contract has become a universal law while the interpretation for the loss of the party which proposes the clause of any contract is enacted assertively on article 1349 of Indonesian Civil Code.
\end{abstract} code

Keywords-principle law; contract interpretation; parties; civil

\section{INTRODUCTION}

In running a business, a very important thing to do is making a contract before the business itself is conducted. Before the contract is made, it will usually be preceded by a preliminary talk and the next level of negotiations to finalize the possibilities, so that the signed contract is fully mature (complete and clear) [1]. Juridical, an approval is an act that takes place between one or more people who bind himself to another or more (on Article 1313 of Indonesian Civil Code) [2].

Some of agreement of the laws specify a particular form, when the form is not followed, the agreement is not valid. Thus, the written form is not merely an evidentiary tool, but is a condition of having their (bestaanwaarde) agreement for example an agreement to establish a Limited Liability Company with a certificate of notary (on Article 38 of Indonesian Commercial Code) [3].
"If a person makes any contract, then the person is regarded to enter into an agreement for the heirs and the people who have the right thereof" (Art 1318 of Indonesian Civil Code) [4].

The transfer of rights to the heirs is the result of a transition with the general rights (onder algemene title) that occurs to the heirs. The transfer of agreement to the people who have rights based on the special title (onderbizondere titel), for example, the person who replaces the buyer has the right as the owner. The rights attached to the quality of something is called qualitative rights.

The agreement contained in Article 1316 of Indonesian Civil Code is called a warranty agreement. This agreement has no relation to the subject matter of the agreement. In this case, someone who bore a third person instead of clicking the connective dependents, but bind themselves. [5]:

The legitimacy of the approvals requires four conditions

- They agree to bind themselves

- Being proficient to create an engagement

- A certain thing

- A lawful cause

The first two conditions are called subjective requirements because of the two terms on the subject of the agreement. While the latter two conditions are mentioned objective terms because of the object of the agreement. By making a discussion into an agreement, it means that parties must have the freedom of the will. Then the parties do not get any pressure that result in a "defect" for the realization of the will.

The law distinguishes two types of oversight, namely the person (error impersonal) and oversight on the goods being the subject of the agreement (error insubstantial) [6].

In the agreement, especially in the contracts that are contrived, sometimes there are different interpretations of each party establishing the contract. It is actually related to how the rule of law and appropriate interpretation of contracts under a judicial contract require to be studied scientifically, so that any or no parties who deliberately exploit the contract can be recognized. This phenomenon provides special attention to the author to conduct a study by narrating it in a paper. 
Building on the facts above, the issues to be examined in this paper are description of legal principles of contract interpretation under the Indonesian Civil Code and strategies in handling any conflicts that occur between the parties as a resolution. Thus, the objectives of conducting this study are: (1) to identify the legal principles of contract interpretation according to Indonesian Civil Code; (2) to find out how to handle resolution of contracting parties in the event of a conflict. In addition, the results of this study are expected to contribute to all levels of society, whether employers, governments or students who study law science, especially to develop the science of Contract Law and can be the subject of study for legal practitioners, including academics on emerging issues related to Law Contract.

\section{METHOD}

This paper uses scientific method, either to get the data or to process the data. In collecting the data, the author uses a literature research method. Further the data that have been collected is processed by using a data processing method consisting of: Induction Method, Deduction Method; and Comparative Method. These methods are used based on the needs of its user to obtain results that can be accounted for, both scientifically and scholarly.

\section{RESULT AND DISCUSSION}

\section{A. Principles of Contract Interpretation based on Indonesian Civil Code}

In making a contract, although the detail of a contact (agreement), there is always the shortcomings here and there, maybe right, there is a saying, "Nobody is perfect". Similarly, the contractor, there are always those who seem against (teqoeder trouw), resulted in disputes of the parties who make the contract.

Juridically, in the science of Law Contract, it is actually known with 3 (three) methods of contract interpretation, which are as follows [7]:

1) The subjective method of interpretation: According to this method of subjective interpretation, the interpretation of the contract is carried out by holding as optimally as possible on the true intentions of the parties, without overly adhering to the words contained in the contract. This method is also espoused by Indonesian Civil Code, by mentioning it on Article 1343 of Indonesian Civil Code specifying that the interpretation of a contract is made with considering and observing the intentions of both sides of just looking at the words grammatically.

2) The objective method of interpretation: In contrast to the subjective method of interpretation, the objective method of interpretation emphasizes what is written in a contract, rather than looking to the intentions of the parties, especially if the language used in the contract is sufficiently clear. The objective of method interpretation is also in line with the doctrine of "clear understanding" that states that it does not require an interpretation if the language in the contract is meaningfully clear. On Article 1342 of Indonesian Civil Code which also states the same thing.

3) The Interpretation method between the objective and the subjective: However, the interpretation that many occur precisely is that the interpretation that goes along between the objective method of interpretation and the subjective method of interpretation. Indonesian Civil Code also contains many articles that deal with in the middle like this.

- The contract interpretation should be to get a sense of logical / reasonable (reasonably)

- The contract interpretation should be to obtain meaning based on the applicable law and customs

- The contract interpretation should be to obtain an effective and efficient meaning.

Indonesian Civil Code governs the issue of this contract interpretation from Articles 1342 to Article 1351. Those (ten) principles of the contractual interpretation is based on Indonesian Civil Code. The principles of the contract interpretation are as follows [8]:

In Contract Law Science, there are three elements that must be fulfilled in the interpretation of the contract, as follows:

- If the words are clear, they should not be interpreted to deviate from them (on Article 1342). This is what is called with "Doktrin Pengertian Jelas" (plain meaning rule).

- Adjusted to the intentions of the both parties (Art 1343), rather than rigidly adhering to the language of the contract.

- Choosing the most probable understanding to run the contract (on Article 1344).

- Choosing an understanding which is mostly relevant in harmony with the nature of the contract (on Article 1345).

- Being interpreted based on the local custom (on Article 1346).

- The things that are forever in the contract must be considered in every contract (on Article 1347).

- Between 1 (one) clause and other clauses else should be interpreted entirely (on Article 1348).

- Being interpreted based on the loss of the party who requests certain terms (on Article 1349).

- Being interpreted in based on the intentions of the parties in making the contract (on Article 1350) against a very broad word meaning.

- The assertion about something in the contract does not influence against others who are not asserted (on Article 1351).

What is meant by its grammatical interpretation of a contract is that the interpretation of a contract to adhere possibly and is not away from the text of the intended contract. With this, the grammatical interpretation of the contract is 
more formal. While what is meant by the theological interpretation is an interpretation that adheres much to the text sound of the contract, but considers more to the purposes and aims of the contract, either the purposes or aims of the contract or from the making/signing of the contract. Thus, the contract interpretation is grammatically more materialistic and the teleological interpretation is more historical. Because the intentions of the parties were also investigated when the contract was firstly signed in.

According to Indonesian Civil Code, if the language of the contract is clear, the contract interpretation which is contrary to the language of the contract cannot be justified (as intended by on Article 1342 of Indonesia Civil Code). This is what is called the "Doktrin Pengertian Jelas" (Plain Meaning Rule). However, if the language in the contract can still be interpreted, then Indonesian Civil Code more adheres to the teleological model of interpretation than the method of grammatical interpretation.

The Indonesian Civil Code also selects practical interpretations for the contract interpretation. What is meant by the practical interpretation is that the interpretation of an unclear contract so that it has more than 1 (one) definition, then in this case, the definition of the contract is chosen according to a workable understanding rather than choosing a definition that cannot be forced or practiced [1].

In this case, on Article 1344 of Indonesian Civil Code states as follows: " If an agreement can be granted for in 2 (two) kinds of understanding, then a definition should be chosen to possibly make the agreement able to be executed, rather than providing a definition that does not allow an implementation."

The provision of Indonesian Civil Code that requires its practical interpretation which is easily understandable, remembering that when making the contract, definitely the parties wants the contract to be implemented so that with the practical interpretation, the approach is also closely a contract with the will of the contract maker.

\section{B. Settlement of the Disputes in the Contract of the Parties}

When we run business transaction with party or in a contract that is signed together, then in the contract that has been signed together, it is always mentioned in a separate article stating how to find out a solution over any conflict or dispute arising [9]:

\section{1) Court way}

In the business world, a relationship occurs between parties which are included in the bonds of civil relationships. Therefore, if there is a breach of a contract (breach of contract), will be resolved in a civil way. The settlement of this case must be preceded by a lawsuit to the court in the jurisdiction of the defendant.

The process in this court will generally be settled through peace efforts by a civil court judge. That peace can be settled out of court. If this can be achieved, then the lawsuit will be revoked by the plaintiff with or without the consent of the defendant. But the peace making can be settled in court. This possibility is made at the recommendation of a judge if peace is resolved by the parties, then during the trial, a peace certificate will be established, in case, the both parties are punished to comply with the agreement made. This peace certificate has the same legal power as the judge's verdict.

If the peace solution cannot be resolved by the parties, the subsequent settlement process will usually take a long time. For a minimum of three levels of court process will be undertaken to arrive at the final process, starting from the lawsuit to the District Court, an appeal to the High Court of Justice, and the last is the process to the Supreme Court. This condition is still common in Indonesia. This means that the expected court process under the law is carried out simply, lightly and quickly and cannot be yet enforced.

\section{2) Arbitration way}

Another alternative that is usually and often performed by businessmen to resolve the dispute that occurs at this time is through arbitration board. For the settlement through this arbitration board has its own characteristics that the business world is really required in its existence. But many of the businessmen who still do not know the function of the arbitration board at all, whereas according to its history, the arbitration was established by the businessmen themselves to resolve a possibility of disputes arising.

The arbitration board is simply an approval line that involves a third party as the referee. In other words, an arbitration is a means of dispute resolution with the assistance of a third party, not a judge, even though in the execution of a judgment, it should be with the help of a judge.

The arbitration is a process of settling or terminating a dispute by a judge or judges who under the agreement will be subject to or comply with the decisions given by the judges they choose or indicate.

The definition above is clear that the legal basis of arbitration is that according to the law is considered normal if two people or parties a involved in a dispute make an agreement and they appoint a third party to whom they are authorized to decide upon a dispute. They also agree to submit to the decision that will be given by the third party. If either party is reluctant to provide assistance for decision-making or does not comply with a decision that has been taken by the person to whom they have authorized the dispute, that party is regarded to have breach of contract or breach of the agreement.

Since 1999, Indonesia has had legislation as a legal basis of using the arbitration board, namely the Law No. 30 of 1999 on Arbitration and Alternative Dispute Resolution which came into force on 12 August 1999. This law is a substitution of article 615 until 651 Reglement of Civil Procedure (Reglement of de Rechtsvoerdering, Staatsblad 1847: 52) [10]. The law provides for the settlement of a dispute between the parties in a particular legal relationship which has made an arbitration agreement which firmly states that all disputes or differences of opinion arising out of legal relations shall be settled by means of arbitration or through a dispute settlement alternative. With respect to the parties that have been bound by the arbitration agreement, there shall be no authority of the District Court to adjudicate the dispute arising from such parties. 
Do any disputes occur can be resolved through arbitration? The answer is certainly not! For as has been mentioned above that the only dispute in the business world is included in the scope of settlement by arbitration such as, issues of trade, industry and finance while civil disputes such as, inheritance, adoption, housing, labor and others, not may be settled by the arbitration board.

The parties to the agreement that are called for the early settlement of arising disputes will be resolved by arbitration, and can use one of two ways to open the existence of refereeing, namely [10].

- By stating a clause in the principal agreement, which contains that any dispute settlement that may arise will be settled by the referee's judiciary. This method is called pactum de compromittendo

- With a separate agreement, outside the principal agreement. This Agreement is made specifically when a dispute arises in the implementation of the principal agreement. Such an agreement is called a "compromising certificate ". This compromising certificate is written in a certificate and is signed by the parties. If the parties cannot sign, the compromising certificate must be made before the notary and witnesses. The compromising certificate contains the main points of dispute, the name and residence of the parties, as well as the arbitrators' residence, whose number is always odd.

By using the arbitration board in the settlement of a dispute, there are at least 3 (three) benefits that can be obtained, namely:

a) Precise time: For the business world, the time to solve a problem or dispute is something very valuable. While the way through the court is very unfavorable, because suing in front of a civil procedure is a very long way. The decision of the District Court is not yet a binding legal force, because there is still a level of appeal to the Higher Court of Justice and a cassation to those who are not satisfied with the decision of the District Court. This process will certainly take a long time. Not to mention the arrears of the case, which led to the increasing length of court settlement process. Therefore, an alternative arbitration institution is an appropriate means for the business world.

b) The existence of people who are experts: With an arbitration board, the parties may appoint well-informed experts on the subject matter of dispute. Thus the verdict he will take will be supported by an in-depth knowledge of the things that are disputed. In arbitration, beside legal experts, there are also other experts in various fields such as banking, insurance, contracting, shipping, labor and others.

c) Secrets of the guaranteed parties: That the examination or dismissal of a dispute by an arbitral tribunal is always conducted with a closed door, so that the secrets of the parties to the dispute will be stored well and will not be known publicly. If a company is known by the public that the company has a lot of debt and is prosecuted before the court, it will harm the good name of the company. In addition, unlike the court decision, the arbitral verdict will never be published in the mass media.

In practice there are two kinds of arbitration, namely adhoc/voluntair arbitration and arbitration as permanent body arbitration. Arbitration ad-hoc/voluntair is an arbitral tribunal (arbiter) or sole arbitrator who performs his duties only once, after which the arbitrator or sole arbitrator disperses. In addition to not having rules or procedures on the appointment of arbitrators, they also do not have rules or procedures of how to govern the procedures for dispute resolution.

While the arbitration as a permanent body arbitration, is an arbitration body that has rules or procedures and mechanism of dispute inspection. The examples are BANI (Arbitration Board of Indonesia) London Arbitration, American Arbitration, ICC Arbitration (International Chamber of Commerce Arbitration) and others.

Considering the importance of arbitration, our businessmen Indonesian businessmen do not have the sincerity to be in the back line in utilizing this arbitration board, especially after the Indonesian government ratified the Convention on the Recognition and Enforcement of Foreign Arbitral Awards (A convention on the recognition and implementation of decisions of foreign arbitration which has been known as the New York Convention 1958) by Presidential Decree No. 34 Year 1981 dated on August 5, 1981 and the Convention on the Settlement Disputes between states and national of other state (a convention on the settlement of disputes among countries and other foreign citizens regarding capital investment, better known as World Bank Convention).

This convention has been approved by the government by Law No. 5 of 1968. In Indonesian businessmen, any sort of business relationship establishes cooperation with foreign parties especially in order to attract foreign investment into Indonesia, has tried to take advantage of this board. As a consequence, in terms of international law, Indonesia has been bound by the New York Convention 1958 since the ratification. In addition, the New York Convention also uses the principle of reciprocity, meaning that this foreign award can be executed by Indonesia if in other contracting state countries can execute the similar things.

\section{CONCLUSION}

The principles of contract interpretation based on Indonesian Civil Code has 3 methods namely: (1) a subjective interpretation method is where the contract interpretation is designed by following optimally possibly from what is meant truly from the side. (2) the objective interpretation method stresses on what is written in any contract (3) the interpretation method between the objective and subjective one is that an interpretation that deals with between the objective interpretation method and the subjective one. The contract interpretation causes the contract maker to be based on 1 in the contract interpretation principle namely the lost principle of the one who proposes or makes it, which means if a clause in a contract proposed by one of the parties, then the interpretation of the clause is made for losses the parties proposed clause. 


\section{ACKNOWLEDGEMENT}

The author would like to thank all the parties who have helped and contributed in the writing of this article, both those who contribute in the form of funding and critical ideas. Hopefully this paper can be useful theoretically and practically for the addition and development of knowledge, especially in the field of legal science.

\section{REFERENCES}

[1] Richard Burton Simatupang, Aspek Hukum dalam Bisniss, Rineka Cipta, Edisi Revisi, Jakarta. 2003, p. 89.
[2] Mariam Darus Badrulzaman, Aneka Hukum Bisnis, Alumni, Bandung, 1994, p. 18

[3] R. Subekti, R. Tjitrosudibio. Kitab Undang-undang Hukum Dagang, Pradnya Paramita, Jakarta, 1984, p. 10

[4] Niniek Suparmi, Kitab Undang-undang Hukum Perdata, Rineka Cipta, Jakarta, 1991, p. 334

[5] Article 1320 of Indonesian Civil Code

[6] Subekti R, Aneka Perjanjian, Rajawali Press, Bandung, 1981, p 20.

[7] Fuady Munir, Hukum Kontrak, Citra Aditya Bakti, Jakarta, 2003, p. 11.

[8] Harahap Yahya M, Segi-segi Hukum Perjanjian , Alumni, Bandung, 1986, p. 120.

[9] Moch. Faisal Salam, Penyelesaian Sengkete Bisnis secara Nasional dan Internasional, Mandar Maju, Bandung, 2007, p.15.

[10] Bambang Sutiyoso, Penyelesaian Sengketa Bisnis, Cet. 1, Citra Media, Yogyakarta, 2006, p. 56 